Dig. Surg. 1985;2:I-IV

\title{
Contents, Vol. 2, 1985
}

\section{No. 1}

No. 2

Original Paper

Surgical Treatment of Adenocarcinoma of the Gastroesophage-

al Junction. Results of a European Questionnaire (GEEMO)

Hölscher, A.H.; Siewert, J.R 1

Pathogenesis of Local Recurrence after Surgical Treatment of Rectal Carcinoma

Hermanek, P.; Gall, F.P.; Guggenmoos-Holzmann, I.;

Altendorf, A 7

Radionuclide Biliary Scanning in the Diagnosis of Gallstone Pancreatitis

Downing, R.; Timmins, A.E.; Watkins, E.; Ward, R.S.;

Black, J.; Windsor, C.W.0 15

The Pepsins of Gastric Juice in Peptic Ulceration and Gastric

Carcinoma

Armstrong, C.P.; Dixon, J.M.; Taylor, TV

19

Drug-Associated Recurrent Pancreatitis

Anderson, J.R.; Johnston, G.W.; Kennedy, T.L 24

Evaluation of En Bloc Radical Pancreatectomy for Carcinoma

of the Head of the Pancreas Involving the Adjacent Vessels

Manabe, T.; Suzuki, T.; Tobe, T

Total Gastrectomy in the Aged with Special Reference to Post operative Convalescence and Return to Normal Life

Koga, S.; Oda, M.; Kaibara, N.; Hisaki, T 31

Case Reports

Gastrocolic Fistula in Chronic Intestinal Ischaemia. Report of a

Case Cured by Splanchnic Revascularisation

Schlosser, V.; Lausen, M.; Wenz, W 36

Spontaneous Hemoperitoneum through Rupture of a Primary

Malignant Tumor of the Liver. Therapeutic Possibilities

concerning Six Cases

Palot, J.P.; Flament, J.B.; Delattre, J.F.; Caulet, T.; Payen, L. 40 Small Intestinal Evisceration through the Anus due to Spontaneous Rupture of the Rectosigmoid

Numata, M.; Ito, N.; Koike, H.; Maeda, T 45

Subtotal Colectomy for Inflammatory Disease of Bowel in a

Patient with Hemophilia A

Nudelman, I.; Kott, I.; Stelman, E.; Reiss, R 47

New Techniques and Procedures 
A New Improved Flexible Choledochoscope: Preliminary Experience (With 1 color plate)

Jakimowicz, J.J.; Carol, E.J.; Haeck, L.; Adhin, S.K. ... 49

Treatment of Esophageal Varices: Transection of the Thoracic

Esophagus with an Oesoclip, without Digestive Opening

Berard, $\mathrm{P} \quad 53$

Original Paper

Acute Appendicitis: Clinical versus Histologic Diagnosis. A

Critical Review of 1,000 Cases

Argov, S.; Timna, A 61

Infectious Complications following Pancreatic Surgery

Blenkharn, J.I.; Blumgart, L.H 65

Endotoxin Levels in Portal and Systemic Blood

Brearley, S.; Harris, R.I.; Stone, P.C.W.; Keighley, M.R.B. 70 Modified Girard Operation for

Esophageal Achalasia (With 1

color plate)

Tanaka, T.; Sato, H.; Morikawa, H.; Matsushita, T.; Yoshi-

da, K.; Sakabe, T 73

Intraoperative Ultrasonography of the Pancreas Based on 32

Observations

Hernigou, A.; Plainfosse, M.C.; Billebaud, T.; Alexandre,

J.H.; Vaucamps, P.; Bouillot, J.L 79

Cystic Dilatation of the Common Bile Duct. Analysis of 13

Cases

Saubier, E.C.; Gouillat, C; Samaniego, C; Ceulemans, O.. 87 Treatment of Refractory Ascites by

Retransfusion and Perito-

neovenous Shunting

Volk, B.A.; Schölmerich, J.; Wilms, H.; Hasler, K.; Kött-

gen, E.; Gerok, W 93

Pancreatitis in Primary Sclerosing Cholangitis

Thompson, J.N.; Collier, N.A.; Blumgart, L.H 98

Indication of Low Anterior Rectum Resection. Method, Results, Prognosis

Probst, M.; Ungeheuer, E 104

Case Reports

Pancreatic Pseudocyst of the Mediastinum: Case Report and

Review of the Literature

Pickford, M.A.; Czerniak, A.; Galland, R.B.; Gibson, R.N.;

Blumgart, L.H.; Benjamin, I.S 109

Posttraumatic Pseudocyst of the Pancreas: Intussusception of

the Defunctionalized Jejunal Loop after Pseudocyst Jeju-

nostomy

Catrambone, G.; Parodi, A.; Iurilli, L.; Gori, A.; Derchi, L. 113 Perianal Tuberculosis: Report of a Case and Review of the

Literature

Gutman, H.; Kott, I.; Santo, M.; Mor, C; Reiss, R. ... 118

Correspondence 
Lateral Stooping Position on Diagnosing Pelvic-Occupying Diseases and Lesions of the Rectum and Rectosigmoid Junction Yung, A.-Y.; Chen, H.-Y.; Zhang, J.-J.; Zhang, M.-G. . . 57

Erratum

60

IV

Contents

No. 3

No. 4

Original Paper

Frequency of Anatomical Hazards during Cholecystectomy

Merenstein, D.; MacGowan, K.M.; Kune, G.A 121

Acute Pancreatitis following Renal Transplantation

Salem, R.R.; Williams, G.; Blumgart, L.H 126

Postsplenectomy Infections in 208 Traumatized Splenecto-

mized Patients from 1971 to 1979

Helpern, E.; Nagler, A.; Argov, S.; Tatarsky, 1131

CEA in Tissue and Serum of Patients with Gastric Cancer

Wittekind, C; Kirchner, R.; Wachner, R.; Henke, W.;

Kleist, S. von 135

Changing Anatomical Patterns of Large Bowel Cancer - A Left

to Right Shift

Greene, F.L 140

Lack of Evidence for Adenoma-Carcinoma Sequence in Chemically Induced Colonic

Carcinogenesis in Rats

Izbicki, J.R.; Hamilton, S.R.; Izbicki, W.; Blòchl, H.;

Dornschneider, G.; Adamek, L.; Kusche, J 143

Diagnostic Value of Fiberoptic Sigmoidoscopy: Evaluation of

the Anatomical Extent

Gabrielli, F 152

The Pros and Cons of Lymphadenectomy in Association with

Rectal Excision for Carcinoma of the Rectum

Shindo, K.; Yasutomi, M.; Takahashi, T.; Koyama, Y.;

Mori, T.; Kajitani, T.; Jinnai, D 158

Case Reports

Leiomyosarcoma of the Esophagus

Chalkiadakis, G.; Wihlm, J.M.; Weill-Bousson, M.; Lion,

R.; Morand, G.; Witz, J.P 164

Massive Hemorrhage from a Congenital Gastric Diverticulum

Moore, J.P.; Richardson, J.B.; Ferrara, J.J 169

Annular Pancreatic Pseudocyst Causing Gastric Outlet Ob

struction and Esophageal Reflux

Aufiero, T.X.; Martin, L.F 172

Carcinoid of the Ampulla of Vater

Wackym, P.A.; Sawyers, J.L.; Glick, A.D.; Gray, G.F., Jr. 176 
Fibrous Histiocytoma of Colon and Pancreas. Report of 2

Unusual Cases and Review of the Literature

Kukora, J.S.; Bagnato, J.; Gatling, R.; Maher, J.W 180

Review Article

Gastric Restrictive Procedures in the Surgical Management of

Morbid Obesity

O’Leary, J.P.; Wickbom, G.; Cha, S.-0 185

Original Paper

Pancreatic Abscess

Maroske, D.; Röher, H.-D 192

Surgical Treatment of Perforated Gastric Cancer

Miura, T.; Ishii, T.; Shimoyama, T.; Hirano, T.; Tomita, M. 200

Bipolar Electrocoagulation of the Nonbleeding Visible Vessel (With 1 color plate) Schlesinger,

P.K.; Donahue, P.E.; Mobarhan, S.; Layden, T.J. 205

Clinical Spectrum and Diagnostic Strategies in Non-Calculous Lower Bile Duct Obstruction

Søreide, O.; Kelley, C.J.; Czerniak, A.; Hadjis, N.S.; Ed

wards, W.H., Jr.; Blumgart, L.H 209

Intramural Hematoma of the Small Intestine: a Plea for Ab

stention

Guivarc'h 215

Enterovaginal Fistula in Crohn's Disease

Dongen, L.M. van; Lubbers, E.-J.C 221

Interactions of Motilin and Neurotensin on Feline Gastrointestinal Motility and Lymph Flow Hirata, T.; Nagai, T.; Fujimura, M.; Pfeiffer, C.J.; Yajima,

H.; Tobe, $\mathrm{T} 225$

Case Report

Massive Fulminant Hemorrhage due to Splenic Vein Rupture in Pancreatitis

Negro, P.; Flati, G.; Flati, D.; Porowska, B.; Tuscano, D.;

Bianchini, A.; Carboni, M 231

Author Index 235

Subject Index 236 